\title{
Identification of Distinctive Usability Critical Factors for Mobile Applications
}

\author{
Anupam, Dr. Tulika \\ SHUATS, Allahabad, India \\ nupamsharma243@gmail.com, tulika.tulika@shiats.edu.in
}

\begin{abstract}
The advancement of subjective programming has been considered as an indispensable part of programming. With the allencompassing call for of portable projects clients, the most awesome aspect the phone projects will turn into a principle concern. The scope of examination shows issues even as the convenience of mobile applications and proposed different systems for its assessment. Anyway not one of the models proposed offers a comprehensive way for evaluating the convenience of cell applications or applications. For this, one requires to initially choose the critical factors and its sub factors on which usability depends. The paper, is about the vital thought of ease of use of versatile applications and proposes eleven Usability Critical Factors (UCF) and sixteen sub-factors that should be mulled over while evaluating usability of Mobile applications.
\end{abstract}

Keywords:

Mobile application, Usability, Critical Factors, Quality.

Article Received: 18 October 2020, Revised: 3 November 2020, Accepted: 24 December 2020

\section{Introduction}

Mobile applications, typically alluded as cell applications that are essentially pc codes progressed explicitly for hand held peripherals devices, holding as a top priority the functionalities provided by methods for telephones and tablets [16]. The underlying objective of those applications is to change cell phones into more modest than normal forces to be reckoned with of potential, robotization and interesting. Cell applications are a stream away from the included programming program frameworks normally situated on PC frameworks, in a way, these applications oversee restricted, remoted and specific ability comprising of computer games, office suites, adding machines, record supervisors, and so forth. In specific fields, applications can likewise have forestalled the thoughts of performing multiple tasks due to the compelled equipment resources of the starter and crude hand-held gadgets. Be that as it may, in a sharp assessment to this, their explicitness is as of now a piece of their appealing extraordinary and rising interest because of the reality they license customers pick and settle onto the capacity and highlights they need their gadgets to have.

Cell applications are assumed to work with unexpected impulsions in comparison to their PC reciprocals, as customers have unmistakable necessities from them. Cell phones are expected to be little adequate to position to utilize by means of hand, sufficiently minimal to be movable consequently they stand a road distant from work areas and workstations. Inferable from those reasons, cell apps are seen with positive constraint in different degrees influencing the working qualities of an app progressed with a technique to chip away nearby held frameworks [19] [21].

Down to the point of reference sign or thereabouts, cell phones had been generalized to have little screens, restricted capacity, low preparing abilities, hard to apply, less intelligent and terrible availability to networks. In addition, essentially disregard about the web; it was a pristine beginning. Additionally, to this, there were a serious small bunch of organizations 
managing underway mobiles and their relating programs. This decade has seen the transformative growth inside the circles of cell innovation, portable availability, cell figuring and cell knowledge. Versatile devices have now given a more extensive assortment of show sizes, goals and issue proportions, expandable memory limits, ad libbed processor capacities, 6th experience advances, contact functionalities, intuitive and easy to understand GUI, simple to utilize apps which further transfer the components of robotization, pleasure and cleverness to our ordinary lives [12] [22].

The fundamental target of those applications is to convincingly run the exhibit, from utility, effectiveness, and way to delight, computer games, prosperity, and pretty much any $n$ segments of others boundaries reasonable. Webprincipally based long range interpersonal communication as an example, has become one in everything about thriving prerequisite which is piercingly blending through totally everybody's presence; that is one a significant number of the most remarkable repercussions of this intense programming program advancement. An app deal pattern exhibited the very actuality that before the extraordinary and wholehearted standing of cell gadgets, programming's were intended to run on PCs and workstations. Tabs and advanced cells are really overwhelming the use of registering gadget PCs and workstations. In actuality spotlight got tossed at the expectation that 197 billion applications have been check to be downloaded in 2020. appropriately, various designers have swung to a "adaptable first" viewpoint, mirroring a similar example in site structure [17].

Nowadays, programming program engineers are looking forward to making solid applications on the grounds that the capacity to withstand abrupt circumstances and conditions is the thing that various applications need them. A more perplexing technique comprises of developing mostly for the versatile condition, abusing the two its guidelines and central components. Developers are carefully setting various functionalities into their applications so as to outperform the set top notch prerequisites [23].

Defending splendid necessities is unendingly an endeavor for programming engineers. In programming, it has been continually an issue to improve quality in a sufficient time with ease. In past numerous years, accommodation of compact applications has raised especially and all together its undertaking toward high-type [29] [30] [31] [32] [33] [34]. A decent quality with respect to a relationship of controls constrained to the system that characterizes a piece in advancement, building up, for instance, how usable, engaging, brief or dependable it's miles [13] [14] [35]. Convenience being one of the pivotal components for surveying most amazing aspect any versatile programming application serves various inconveniences [18] [24] [20]. It's being a most effortless approach to improve the quality and conviction of the client toward the product application. As per ISO, ease of use is an "degree to which an item can be utilized by indicated clients to accomplish determined objectives with viability, effectiveness and fulfillment in a predefined setting of utilization". Usability covers a few perspectives, like accommodation, personalization, straightforwardness of becoming acquainted with, and receptiveness. It's a squeezing agreeable prerequisite for a more extensive assortment of programming applications.

The current work centers around an approach to make applications subjective in nature. For this, different significant components and its subfactors that influence convenience are recognized through the writing and expert's assessment working in the order of programming program designing. This permits engineers to mindfulness more on ease of use of the utility to create subjective versatile application.

\section{LITERATURE REVIEW}


Different techniques have been characterized to survey ease of use of cell programs through remarkable specialists. One of the models characterized assesses ease of use principally dependent on its components, by means of giving progressive construction to it and furthermore different rating approaches was utilized to assess components [5]. Other methodology utilized by Kortum and Sorber [6] to survey convenience, by means of settling on 10 cell applications fundamentally dependent on their standing and giving a poll to satisfactory number of clients and getting scores from them. Kronbauer et. al. [8] assesses 3 particular android versatile applications, the utilization of perspective orientated programming in it. Though, Kluth et. al. analyzed ease of use handiest for portable projects that sudden spikes in demand for iOS working gadget dependent on their comparable example event and arrangement of cooperation.

Assortment of hardware has been planned with the guide of different analysts to report utility exercises that are identified with portable individual cooperation to assess ease of use [7] [9] [10] [11]. Ryu et al. [3] give a cell phone ease of use poll [MPUQ] to cell phone clients and look at the outcomes for versatile bundles over the long haul client market. Grossman et al. [4] gave a strategy named as Tool Clips, offering a video clasp to clients that apparent as a manual for utilizing a product, for example, printed content guide. Gafni [2], provided convenience estimates which may be remarkable to cell gadgets even as breaking down cell remote realities structures. These convenience measures were connected with Wi-Fi cell related issues that permits you to assess ease of use. Hussain et al. [1] provided an ease of use metric system for versatile applications, and check the ease of use the utilization of expectation inquiry metric that incorporates straightforwardness, wellbeing and other related measurements as an examiner.

Accessing and contrasting quality leads a urgent capacity while performing quality guarantee rehearses. Satisfying purchaser assumptions for subjective cell application has been an endeavor with expanded requirements. Henceforth, it expects engineers to build nature of items that a client can use with no issues with insignificant endeavors. Hence, it requires developers to increase quality of products that a user can use without any problems with minimal efforts. In the present research work, different usability essential factors which are vital to achieve good quality usable mobile app get determined.

\section{USABILITY CRITICAL FACTORS}

In the current work, in light of the survey done and expert's assessment running inside the subject of cell utility turn of events, eleven convenience basic elements i.e. UCF and 16 subcomponents are perceived which may be basic for evaluating ease of use of a portable application programming [36]. The 11 Usability Crucial Factors (UCF) include availability, instinctive representation, customer experience, traceability, navigation, efficacy, functional design, feasible, comprehensibility, coherence and clearness [27] [28]. Each of the factor identified plays a vital role while measuring the whether a particular cellular application consist of with good usability. Which in turn defines as one of the qualitative factor for evaluating quality of the application. As usability may be perceived differently by different customers, so, each factor may behave differently for them respectively. Therefore, each factor determined is important from the software application developer's point of view as well as with customer's point of you. All the eleven UCF are briefly described in Table 1. 
Table 1: Usability Critical Factors (UCF)

\begin{tabular}{|c|c|}
\hline $\begin{array}{l}\text { Usability Critical } \\
\text { Factors }\end{array}$ & Description \\
\hline Availability (UCF1) & This refers to "low tons the software is effortlessly available to the user". \\
\hline $\begin{array}{l}\text { Instinctive Representation } \\
\text { (UCF2) }\end{array}$ & $\begin{array}{l}\text { The layout of the software program application performs a important position for } \\
\text { the usability of the utility. }\end{array}$ \\
\hline $\begin{array}{l}\text { Customer Experience } \\
\text { (UCF3) }\end{array}$ & $\begin{array}{l}\text { This refers to the person scores and critiques of the users who already using the } \\
\text { utility. }\end{array}$ \\
\hline Traceability (UCF4) & This refers to the benefit with which cell software is findable. \\
\hline Navigation (UCF5) & $\begin{array}{l}\text { This defines the convenience with which a web page may be navigated to } \\
\text { different pages inside the utility. }\end{array}$ \\
\hline Efficacy (UCF6) & This refers to "Low accurate consumer perceives the application". \\
\hline Functional Design(UCF7) & $\begin{array}{l}\text { This refers to the how a great deal the developers are running at the betterment } \\
\text { usability of the utility. }\end{array}$ \\
\hline Feasible (UCF8) & $\begin{array}{l}\text { This refers to the convenience of operability of the cellular utility for the } \\
\text { customers. }\end{array}$ \\
\hline $\begin{array}{l}\text { Comprehensibility } \\
\text { (UCF9) }\end{array}$ & $\begin{array}{l}\text { This refers to the clarity of the textual content, clearness; of the application while } \\
\text { the usage of it by way of the person. }\end{array}$ \\
\hline Coherence (UCF10) & This defines the performance of the utility in attitude of usability i.e (ease of use). \\
\hline Clearness (UCF11) & $\begin{array}{l}\text { This refers to the expertise such that user can easily use the application as a user } \\
\text { pleasant mobile software. }\end{array}$ \\
\hline
\end{tabular}

With the concern to focus in additional on the decided eleven factors it's likewise fundamental to distinguish that how, these variables be gotten to [26]. Thus, the characterized sub-factors are the estimation for the ease of use fundamental elements for example UCF. While building up an application planner should deal with all these UCF and sub-variables to make versatile applications more usable and well disposed. This permits clients to utilize the application for additional time with a decent quality worth. These 16 sub-factors are portrayed in Table 2 .

Table 2: Essential Usability Sub-Factors to Assess Usability

\begin{tabular}{|c|c|}
\hline Usability Sub-Factors & $\begin{array}{l}\text { Description } \\
\end{array}$ \\
\hline Cross Platform (CP) & $\begin{array}{l}\text { A machine software program or product operates on a couple of operating } \\
\text { environments. In different words you can say that it must be a platform } \\
\text { independent technique. }\end{array}$ \\
\hline Cognitive Load (CL) & $\begin{array}{l}\text { It is the effort getting used inside the working memory. That is, how the } \\
\text { information is offered to the person. }\end{array}$ \\
\hline Reaction Time (RT) & $\begin{array}{l}\text { It's the elapsed time among an inquiry on a device and the response to that } \\
\text { inquiry. This is used to investigate the overall performance of the device. }\end{array}$ \\
\hline Mistake Frequency (MF) & $\begin{array}{l}\text { This refers to the distinction between the actual and scheduled frequency or we } \\
\text { will say that how often mistakes encountered in keeping with unit time. }\end{array}$ \\
\hline Appearance (VA) & $\begin{array}{l}\text { This refers to the person interface of the software i,d how the person perceives to } \\
\text { it. }\end{array}$ \\
\hline Information Structure(IS) & $\begin{array}{l}\text { Different branches of data device have the distinct structure; it represents the } \\
\text { structural layout of the recorded environment. }\end{array}$ \\
\hline Supportive Version (SV) & $\begin{array}{l}\text { This refers to quite a number of the software program and products which assist } \\
\text { the existing hardware }\end{array}$ \\
\hline Complexity (COM) & $\begin{array}{l}\text { This refers in terms of complex task to be completed in the maximum efficient } \\
\text { way. }\end{array}$ \\
\hline $\begin{array}{l}\text { Technological Interactivity } \\
\text { (TI) }\end{array}$ & This refers to the interactional social association between the actors. \\
\hline $\begin{array}{l}\text { Customer Satisfaction } \\
\text { (CS) }\end{array}$ & $\begin{array}{l}\text { This refers to the proportion at which person is satisfied with the operating of the } \\
\text { software. }\end{array}$ \\
\hline Customer Feedback (CF) & It is the revel in of users to the offerings, software, products. \\
\hline Information Access (IA) & $\begin{array}{l}\text { It is the ability of a consumer to get right of entry to records or resources at a } \\
\text { distinctive place and in an appropriate layout. }\end{array}$ \\
\hline Device Crash (DC) & $\begin{array}{l}\text { This refers to the way in which consumer information will not get affected due to } \\
\text { some system failure. }\end{array}$ \\
\hline Expressiveness (EX) & This refers to in which manner the software isn't the same as other programs. \\
\hline Variance (VAN) & $\begin{array}{l}\text { This refers to the appearance of the software utility in phrases of user } \\
\text { satisfaction. }\end{array}$ \\
\hline $\begin{array}{l}\text { Customer Eng } \\
\text { (CE) }\end{array}$ & $\begin{array}{l}\text { In the course of the improvement of product, the UE refines till the final product } \\
\text { is correct in step with the specification or now not. }\end{array}$ \\
\hline
\end{tabular}

\section{CONCLUSION}

The current work talks about the meaning of convenience of portable apps as the significant component for creating good quality cell application. In light of on the study done and expert's assessment employed in the region of versatile application improvement, 11 convenience significant variables i.e. UCF and 16 sub-factors has been perceived for the assessment cause. From the results, it's been reasoned that the instinctive plan of an app defines a fundamental position while building up a usable application. Likewise, significant basic components can be analyzed to build up a subjective versatile programming. In future, these recognized elements might be utilized for assessing the convenience of any versatile application to decide its quality comprehensively.

\section{REFERENCES}

[1] A. Hussain and M. Kutar, "Usability Metric Framework for Mobile Phone Application," The 10th Annual Post Graduate Symposium on The Convergence of Telecommunications, Networking and Broadcasting, pp. 22- 23, 2009. 
[2] R. Gafni, "Usability issues in mobilewireless information systems," Issues in Informing Science and Information Technology, Vol. 6, pp. 755-769, 2009.

[3] Y. S. Ryu, "Development of usability questionnaires for electronic mobile products and decision making methods," Dissertation Submitted to the Faculty of Virginia Polytechnic Institute and State University in Partial Fulfillment of the Requirements for the Degree of Doctor of Philosophy in Industrial and Systems Engineering, 2005.

[4] T. Grossman, and G. Fitzmaurice, "ToolClips: An investigation of contextual video assistance for functionality understanding, "in Proceedings of 28th International Conference on Human Factors in Computing Systems, pp. 15151524, ACM, 2010.

[5] J. Heo, D. H. Ham, S. Park, C. Song, and W. C. Yoon, "A framework for evaluating the usability of mobile phones based on multi-level, hierarchical model of usability factors," Journal of Interacting with Computers, pp. 263- 275, 2009.

[6] P. Kortum, and M. Sorber, "Measuring the Usability of Mobile Applications for Phones and Tablets," International Journal of Human- Computer Interaction, pp. 518529, 2015.

[7] W. Kluth, K. H. Krempels, and C. Samsel, "Automated Usability Testing for Mobile Applications," in Proceedings of $10^{\text {th }}$ International Conference on Web Information Systems and Technologies, pp.1-8,2014.

[8] A. H. Kronbauer, C. A. S. Santos, and V. Vieira, "Smartphone Applications Usability Evaluation: A Hybrid Model and its Implementation," in Proceedings of 4th international conference on HumanCentered Software Engineering, pp. 1-18, 2013.
[9] F. Lettner, and C. Holzmann, "Usability Evaluation Framework Automated Interface Analysis for Android Applications," in Proceedings of International Conference of Computer Aided Systems Theory, pp. 560-567, 2011.

[10] B. Shivade, and M. Sharma, "Usability Analyzer Tool: A Usability Evaluation Tool For Android Based Mobile Application," International Journal of Emerging Trends \& Technology in Computer Science, pp. 247-252, 2014.

[11] X. Ma, B. Yan, G. Chen, C. Zhang, K. Huang, and J. Drur, "A Toolkit for Usability Testing of Mobile Applications," in Proceedings of Third International Conference (MobiCASE), pp.1-20, 2011.

[12] P. K. Aggarwal, P.S. Grover, and L. Ahuja, "Security Aspect in Instant Mobile Messaging Applications," in Proceedings of IEEE International Conference on Recent Advances on Engineering, Technology and Computational Sciences (RAETCS), pp.1-5, 2018.

[13] P. K. Aggarwal, P.S. Grover, and L. Ahuja, "Incorporating Autonomic Capability as Quality Attribute for Software Systems", In Proceedings of IEEE International Conference on Reliability, Infocom Technologies and Optimization, 2018.

[14] P. Jain, A. Sharma, and L. Ahuja, "The Impact of Agile Software Development Process on the quality of Software Product", In Proceedings of the 5th International Conference on Reliability, Infocom Technologies and Optimization (Trends and Future Directions) (ICRITO), 2018.

[15] J. Figueira, S. Greco, and M. Ehrgott, "Multiple Criteria Decision Analysis: State of the art surveys," Springer, ISBN: 0-387-23067-X, 2005. 
[16] H. Falaki, R. Mahajan, S. Kandula, D. Lymberopoulos, R. Govindan, and D. Estrin, "Diversity in smartphone usage," in Proceedings of the $8^{\text {th }}$ International Conference on Mobile systems, applications, and services (Mobisys'10), pp. 179-194, 2010.

[17] "Number of apps available in leading app stores

2017

Statistic.'[Online]Available:https://www.s tatista.com/statistics/276623/number-ofappsavailable-in-leading-app-stores/.

[18] A. Abran, "ISO 9126: Analysis of Quality Models and Measures," Wiley-IEEE Press, 2010.

[19] P. K. Aggarwal, P.S. Grover, and L. Ahuja, "Evaluating Self-Management Features for Mobile Applications," International Journal of E-Services and Mobile Applications (IJESMA), 2018. (in press).

[20] R. F. Spielberg, "Handbook of reliability, availability, maintainability and safety in engineering design," Springer, London, ISBN: 978-1-84800-175-6, 2009.

[21] A. Ahmad, K. Li, C. Feng, S.M. Asim, A. Yousif, and S. Ge, "An Empirical Study of Investigating Mobile Applications Development Challenges," Special section on software standards and their impact in reducing software failures, IEEE Access, Vol. 6, pp. 17711-17728, 2018.

[22] Z. Jiang, R. Kuang, J. Gong, H. Yin, Y. Lyu, and X. Zhang, "What Makes a Great Mobile App? A Quantitative Study Using a New Mobile Crawler, "IEEE Symposium on Service-Oriented System Engineering (SOSE), pp. 222-227, 2018.

[23] P. K. Aggarwal, P.S. Grover, and L. Ahuja, "Exploring Quality Aspects of Smart Mobile Phones Applications," of Advanced Research in Dynamical and Control Systems (JARDCS), pp. 292-297, 2018.
[24] A. Nitze, and A. Schmietendorf, "A survey on mobile users' software quality perceptions and expectations," in Proceedings of the Eighth International Conference on in Software Testing, Verification and Validation Workshops (ICSTW), pp. 1-2, 2015.

[25] A. Avizienis, J. C. Laprie, B. Randell, and C. Landwehr, "Basic concepts and taxonomy of dependable and secure computing," IEEE Trans. on Dependable and Secure Computing, Vol. 1(1), pp. 1133, 2004.

[26] P. K. Aggarwal, P.S. Grover, and L. Ahuja, "Locating Usability Critical Factors for Mobile Applications Using ELECTRITRI Method", In Proceedings of IEEE International Conference on Confluence, pp. 597-600, 2019.

[27] P. K. Aggarwal, P.S. Grover, and L. Ahuja, "Assessing Quality of Mobile Applications Based On a Hybrid MCDM Approach", International Journal of Open Source Software and Processes (IJOSSP), Vol. 10, Issue 3, Article 4, 2019.

[28] P. K. Aggarwal, P.S. Grover, L. Ahuja, “A Performance Evaluation Model for Mobile Applications", In Proceedings of the International Conference on Internet of Things: Smart Innovation and Usages (IOT-SIU), 2019.

[29] P. Jain, A. Sharma, L. Ahuja, "A Customized Quality Model for Software Quality Assurance in Agile Environment", International Journal of Information Technology and Web Engineering (IJITWE), Vol. 14, Issue 3, Article 4, pp. 64-77, 2019.

[30] P. Jain, A. Sharma, and L. Ahuja, "ISM Based Identification of Quality Attributes for Agile Development", In Proceedings of the $5^{\text {th }}$ International Conference on Reliability, Infocom Technologies and Optimization (Trends and Future Directions) (ICRITO), pp. 615-619, 2016. 
[31] P. Jain, A. Sharma, L. Ahuja, "The Model for Determining Weight Coefficients of Maintainability Criteria in Agile Software Development Process", In Proceedings of the International Conference on Internet of Things: Smart Innovation and Usages (IOT-SIU), 2019.

[32] P. Jain and P.K. Aggarwal, "Mobile Phone Maintainability Prediction using MCDM Methodology", International Journal of Recent Technology and Engineering (IJRTE), Vol. 8, pp. 410-415, 2019.

[33] P. Jain, A. Sharma, L. Ahuja, "Software Maintainability Estimation in Agile Software Development", International Journal of Open Source Software and Processes, Vol. 9, Issue 4, pp. 65-78, 2018.

[34] P. Jain, L. Ahuja and A. Sharma, "Current State of the Research in Agile Quality Development", in Proceedings of the International Conference on Computing for Sustainable Global Development, pp. 1877-1879, 2016.

[35] P. Jain, A. Sharma, P. K. Aggarwal, "Key Attributes for a Quality Mobile Application", in Proceedings of the International Conference on Cloud Computing, Data Science \& Engineering, Confluence, pp. 50-54, 2020.

[36] A. Sharma and Tulika, "Usability Assessment of Mobile Software Applications: A Systematic Review", Journal of Critical Reviews, Vol. 7, Issue 11, pp. 1865-1870, 2020. 